\title{
SELEKSI LIMA ISOLAT FUNGI MIKORIZA ARBUSKULAR UNTUK KELAPA SAWIT (Elaeis guineensis Jacq.) DI PEMBIBITAN
}

\author{
Maria Viva Rini, Kusuma Oka Pertiwi \& Hidayat Saputra \\ Jurusan Agroteknologi Fakultas Pertanian Universitas Lampung \\ Jl. Sumantri Brojonegoro No.1, Bandar Lampung, Lampung 35145 \\ E-mail:kusumaoka28@gmail.com
}

\begin{abstract}
ABSTRAK
Fungi Mikoriza Arbuskular (FMA) merupakan simbiosis antara fungi tertentu dengan akar tanaman dan memiliki kemampuan bersimbiosis hampir dengan $90 \%$ tanaman. FMA tidak memiliki inang yang spesifik, namun tingkat infektivitas dan efektivitasnya berbeda. Pemilihan jenis FMA yang tepat untuk kelapa sawit diharapkan dapat meningkatkan pertumbuhan bibit kelapa sawit di lapangan. Penelitian ini bertujuan untuk menentukan isolat FMA yang terbaik untuk pembibitan kelapa sawit. Perlakuan disusun dalam rancangan perlakuan tunggaltidak terstruktur dengan 6 perlakuan dan 4 ulangan, sehingga terdapat 24 satuan percobaan. Perlakuan yang digunakan yaitu P0 (Kontrol), P1 (Glomus sp. isolat MV 10), P2 (Glomus sp. isolat MV 27), P3 (Gigaspora sp. isolat MV 17), P4 (Entrophospora sp. isolat MV 2), P5 (Entrophospora sp. isolat MV 29). Rancangan percobaan yang digunakan adalah Rancangan Acak Kelompok. Kesamaan ragam antar perlakuan diuji dengan Uji Barlett. Kemenambahan data diuji dengan Uji Tukey. Jika asumsi terpenuhi yaitu ragam perlakuan homogen dan data bersifat menambah, data dianalisis ragam. Pengujian beda nilai tengah antar perlakuan dilakukan dengan uji Beda Nyata Terkecil (BNT) pada selang kepercayaan Q 5\%. Hasil penelitian menunjukkan bahwa FMA jenis Entrophospora sp. isolat MV 29 dan Glomus sp. isolat MV 27 merupakan FMA yang terbaik untuk pertumbuhan bibit kelapa sawit dibandingkan dengan FMA lainnya dan tanpa FMA yang dilihat melalui nilai tengah jumlah daun sebesar 10,5 helai, nilai tengah bobot kering tajuk sebesar 30,7 g dan 29,2 g, nilai tengah diameter batang sebesar 3,98 cm dan 4,02 cm dan nilai tengah persen infeksi akar sebesar $82,9 \%$ dan $75,8 \%$.
\end{abstract}

Kata kunci: Bibit Kelapa Sawit, FMA, Pembibitan, Seleksi.

\section{PENDAHULUAN}

Kelapa sawit (Elaeis guineensis Jacq.) merupakan salah satu tanaman perkebunan yang mempunyai nilai ekonomi yang tinggi. Indonesia merupakan salah satu produsen utama minyak kelapa sawit di dunia. Pengembangan kelapa sawit telah dilakukan secara luas di Indonesia sehingga perlu difikirkan usaha untuk meningkatkan kualitas dan kuantitas produksi kelapa sawit secara tepat. Salah satu aspek agronomis yang tidak terlepas dalam pengembangan kelapa sawit yaitu pembibitan. Menurut Atkinson (2000), salah satu cara untuk meningkatkan pertumbuhan bibit yaitu dengan cara meningkatkan kemampuan bibit dalam mengambil air dan unsur hara dari dalam tanah yang merupakan peranan dari akar.

Fungi Mikoriza Arbuskular (FMA) merupakan simbion obligat yang hidup secara simbiosis mutualisme dengan perakaran tanaman dan tumbuh diantara sel-sel korteks akar. FMAmemiliki kemampuan bersimbiosis hampir dengan 90\% tanaman (Smith dan Read, 2008). Kelapa sawit adalah tanaman yang secara alami dapat bersimbiosis dengan FMA (Rini et al., 2010). Keberadaan FMA dapat meningkatkan efisiensi penyerapan unsur hara terutama fosfor yang ketersediaannya sangat rendah (Prayudianingsih dan Sari, 2016).

Iskandar (2002) menyatakan bahwa prinsip kerja FMA adalah menginfeksi sistem perakaran dari tanaman inang, memproduksi jalinan hifa secara intensif sehingga tanaman yang bersimbiosis dengan mikoriza tersebut akan mampu meningkatkan kapasitasnya dalam penyerapan unsur hara. Keuntungan dari keberadaan FMA selain dapat meningkatkan serapan fosfat dan unsur hara lainnya juga dapat menyerap ion-ion esensial yang secara normal berdifusi secara lambat ke permukaan akar, tetapi dibutuhkan dalam jumlah besar oleh tanaman seperti amunium, kalium, dan nitrat. Manfaat mikoriza ini akan secara nyata terlihat jika kondisi tanahnya miskin hara atau kering, sedangkan pada kondisi tanah yang subur, peran mikoriza ini tidak terlalu terlihat (Lakitan, 2012).

Fungi Mikoriza Arbuskular tidak hanya hidup pada satu jenis tanaman, begitu juga tanaman dapat 
bersimbiosis dengan banyak jenis FMA. Pemilihan jenis FMA yang tepat untuk pertumbuhan kelapa sawit diharapkan dapat meningkatkan pertumbuhan bibit kelapa sawit yang berkualitas sehingga pada akhirnya bibit tersebut mampu tumbuh dengan baik di lapangan. Penelitian ini bertujuan untuk menentukan isolat FMA yang terbaik untuk pembibitan kelapa sawit.

\section{BAHAN DAN METODE}

Perlakuan disusun dalam rancangan perlakuan tunggal tidak terstruktur dengan 6 perlakuan dan 4 ulangan, sehingga terdapat 24 satuan percobaan. Perlakuan yang digunakan yaitu P0 (Kontrol), P1 (Glomus sp. isolat MV 10), P2 (Glomus sp. isolat MV 27), P3 (Gigaspora sp. isolat MV 17), P4 (Entrophospora sp. isolat MV 2), P5 (Entrophospora sp. isolat MV 29). Deskripsi masing-masing FMA disajikan pada Tabel 1. Rancangan percobaan yang digunakan adalah Rancangan Acak Kelompok. Pengelompokan berdasarkan tinggi bibit dan panjang akar. Kesamaan ragam antar perlakuan diuji dengan Uji Barlett. Kemenambahan data diuji dengan Uji Tukey. Jika asumsi terpenuhi yaitu ragam perlakuan homogen dan data bersifat menambah, maka data dianalisis ragam. Pengujian beda nilai tengah antar perlakuan dilakukan dengan uji Beda Nyata Terkecil (BNT) pada taraf selang kepercayaan Q 5\%.

Penyemaian benih dan penyiapan media tanam di Pre nursery. Media tanam yang digunakan untuk penyemaian dan pre nursery yaitu pasir sungai yang telah disterilkan menggunakan autoclave dengan suhu $121^{\circ} \mathrm{Cselama} \pm 1 \mathrm{jam}$. Kemudian pasir dicuci bersih hingga 6 kali. Setelah itu pasir untuk penyemaian di masukkan ke dalam bak semai. Benih kelapa sawit yang baru berkecambah disemai pada media persemaian. Bibit dipelihara di persemaian selama 4 minggu. Sedangkan untuk media tanam di pre nursery, pasir dimasukkan ke dalam polybag berukuran 18 x $25 \mathrm{~cm}$.

Persiapan inokulan. Ada 2 cara persiapan inokulan, yaitu inokulan yang diisolasi terlebih dahulu, dan inokulan tanpa diisolasi. Inokulan yang diisolasi terlebih dahulu yaitu Glomus sp. isolat MV 10, Glomus sp. isolat MV 27, Gigaspora sp. isolat MV 17 dan
Entrosphospora sp. isolat MV 2. Cara isolasi menggunakan teknik penyaringan basah (Brundrett et al., 1996), lalu diamati di bawah mikroskop stereo. Spora FMA yang akan digunakan diambil menggunakan pinset spora lalu dikumpulkan di dalam cawan arloji, kemudian dihitung menggunakan counter. Prosedur ini dilakukan sampai didapatkan 500 spora. Sedangkan untuk inokulan Entrosphospora sp. isolat MV 29 tidak diisolasi. Pada inokulan Entrophospora sp. isolat MV 29 terdapat 961 spora / 50g. Sehingga diperlukan 26,01 g inokulum untuk menyediakan 500 spora per bibit kelapa sawit. Penimbangan dilakukan dengan menggunakan timbangan elektrik.

Penanaman di pre nursery dan inokulasi spora FMA. Benih yang telah disemai selama 4 minggu, dipindah tanam ke dalam polybag yang berukuran $18 \times 25 \mathrm{~cm}$ dengan satu bibit per polybag. Spora dari masing-masing isolat Glomus sp. isolat MV 10, Glomus sp. isolat MV 27, Gigaspora sp. isolat MV 17 dan Entrosphospora sp. isolat MV 2 diambil dengan menggunakan mikropipet lalu disemprotkan secara merata ke seluruh permukaan akar. Inokulum Entrophospora sp. isolat MV 29 yang telah ditimbang, ditaburkan secara merata dan perlahan pada akar-akar bibit hingga inokulum tersebar merata di permukaan akar. Kemudian bibit kelapa sawit yang berada dalam lubang tanam dan telah diaplikasi FMA ditutup dengan media tanam. Selanjutnya bibit disusun di dalam rumah kaca sesuai tata letak percobaan. Bibit dipelihara di pre nursery selama 3 bulan.

Penyiapan media tanam di main nursery. Media tanam yang digunakan pada main nursery yaitu tanah top soil. Sebelum digunakan, tanah dianalisis untuk mengecek spora indigenous sebanyak 3 kali ulangan. Tanah diayak terlebih dahulu menggunakan ayakan tanah, lalu dimasukkan ke dalam polybag yang berukuran $30 \mathrm{~cm} \mathrm{x} 40 \mathrm{~cm}$.

Penanaman di main nursery. Bibit kelapa sawit yang telah berumur 3 bulan di pre nursery ditransplanting ke main nursery secara hati-hati agar akar tidak rusak atau patah. Bibit yang telah ditransplanting disusun sesuai tata letak percobaan. Bibit dipelihara di main nursery selama 3 bulan.

Tabel 1. Deskripsi 5 isolat yang diuji

\begin{tabular}{lccc}
\hline \multicolumn{1}{c}{ Spesies } & Isolat & Asal Daerah & Tanaman Inang \\
\hline Glomus sp. & MV 10 & Gunung Para, Sumatra Utara & Kelapa Sawit \\
Glomusp. & MV 27 & Sekampung Udik, Lampung & Kelapa Sawit \\
Gigaspora sp. & MV 17 & Jember, Jawa Timur & Jarak \\
Entrophospora sp. & MV 2 & Sekampung Udik, Lampung & Kelapa Sawit \\
Entrophospora sp. & MV 29 & Bentar Kersik B, Sumatra Utara & Kelapa Sawit \\
\hline
\end{tabular}


Pemeliharaan tanaman dan pengamatan. Pemeliharaan bibit kelapa sawit yang dilakukan meliputi penyiraman, penyiangan gulma, pengendalian hama dan penyakit, serta pemupukan. Penyiraman dilakukan satu hari sekali. Penyiangan gulma secara manual dengan cara dicabut gulma-gulma yang tumbuh disekitar bibit kelapa sawit dengan menggunakan tangan. Pengendalian hama dilakukan dengan cara manual dengan membersihkan hama yang ada di sekitar tanaman. Pengendalian penyakit dilakukan dengan cara kimiawi yaitu mengusapkan alkohol 10\% ke permukaan tanaman yang terserang. Pemupukan dilakukan dengan menggunakan pupuk urea pada saat bibit berumur 3-8 minggu dengan dosis $2 \mathrm{~g} / \mathrm{L}$ air/ 100 tanaman setiap satu miggu sekali. Kemudian dilanjutkan dengan pupuk NPK $(15: 15: 6,4)$ pada saat bibit berumur 10 minggu dengan dosis 10 g/ $5 \mathrm{~L}$ air/ 100 tanaman, pada saat bibit berumur 1224 minggu dengan dosis $7 \mathrm{~g} /$ tanaman setiap dua minggu sekali, dan pada saat bibit berumur 26 minggu dengan dosis $15 \mathrm{~g} /$ tanaman setiap satu minggu sekali.

Pada akhir penelitian (3 bulan di main nursery) dilakukan pengamatan terhadap variabel persen infeksi akar (\%) dengan rumus:

Persen infeksi

$$
=\frac{\Sigma \text { pengamatan yang positif terinfeksi }}{\Sigma \text { total pengamatan }} \times 100 \%
$$

jumlah daun (helai) yang dihitung pada daun yang terbuka sempurna, diameter batang $(\mathrm{cm})$ yang diukur pada batang terbesar (bonggol) menggunakan jangka sorong, dan bobot kering tajuk (g) dan bobot kering akar $(\mathrm{g})$ yang ditimbang menggunakan timbangan elektrik setelah dikeringkan di dalam oven sampai bobotnya konstan.

\section{HASIL DAN PEMBAHASAN}

Hasil penelitian menunjukkan bahwa pemberian FMA berpengaruh nyata pada persen infeksi akar. Semua jenis FMA yang diinokulasikan pada tanaman bibit kelapa sawit memiliki persen infeksi akar yang lebih baik dibandingkan dengan tanpa FMA. Persen infeksi akar tertinggi diperoleh pada bibit kelapa sawit yang diinokulasi dengan FMA jenis Entrophospora sp. isolat MV 29 yaitu sebesar $82,9 \%$ dan tidak berbeda nyata dengan inokulasi FMA lainnya. Persen infeksi akar terendah diperoleh pada bibit kelapa sawit tanpa FMA yaitu sebesar 51,4\% (Tabel 2). Adanya infeksi akar bibit kelapa sawit tanpa FMA ini karena adanya FMA indigenous dalam media tanah (main nursery) yang tidak disterilisasi terlebih dahulu sehingga menginfeksi akar bibit kelapa sawit. Setelah dilakukan perhitungan spora indigenous, terdapat 18 spora indigenous/ $50 \mathrm{~g}$ tanah yang digunakan. Pada penelitian ini menggunakan media tanah sebanyak 8 $\mathrm{kg} /$ polybag, sehingga populasi spora indigenous sebanyak 2880 spora/ polybag. Banyaknya spora indigenous yang berada di dalam tanah menyebabkan akar tanaman kontrol terinfeksi oleh FMA.

Persen infeksi akar dipengaruhi oleh faktor kesesuaian FMA dengan tanaman inang. Kesesuaian tersebut dilihat dari eksudat akar yang dikeluarkan oleh akar tanaman inang. Diduga semua jenis FMA yang diinokulasikan baik Glomus sp., Gigaspora sp., dan Entrophospora sp., cocok dengan eksudat akar bibit kelapa sawit. Hal ini juga sama dengan hasil penelitian Hadi (2011) bahwa semua jenis FMA yang diaplikasikan baik Glomus sp., Gigaspora sp., dan Entrophospora sp., memiliki persen infeksi akar yang lebih tinggi dibandingkan dengan tanpa FMA pada bibit kelapa sawit.

Menurut Allen (2001), keterpaduan antara inang dengan FMA dapat dilihat dengan derajat infeksi akar inangnya, meskipun belum tentu menggambarkan tinggi rendahnya pertumbuhan tanaman inang. Pengamatan persen infeksi akar dilakukan untuk melihat ada atau tidaknya struktur FMA (hifa internal, arbuskul, dan vesikel) yang berada di dalam akar. Tingginya persen infeksi akar tidak selalu mencerminkan tingginya hifa eksternal yang terbentuk. Sedangkan dalam penyerapan unsur hara dipengaruhi oleh kolonisasi hifa eksternal. Tingginya

Tabel 2. Data persen infeksi akar bibit kelapa sawit umur 28 MST yang telah diinokulasi 5 jenis FMA

\begin{tabular}{lc}
\hline \multicolumn{1}{c}{ Perlakuan } & Nilai tengah persen infeksi akar \\
\hline Tanpa Mikoriza & $51,4 \mathrm{~b}$ \\
Glomus sp. Isolat MV 10 & $66,6 \mathrm{ab}$ \\
Glomus sp. Isolat MV 27 & $75,8 \mathrm{a}$ \\
Gigaspora sp. Isolat MV 17 & 73,0 a \\
Entrophospora sp. Isolat MV 2 & $67,1 \mathrm{ab}$ \\
Entrophospora sp. Isolat MV 29 & $82,9 \mathrm{a}$ \\
\hline \multicolumn{1}{c}{ BNT 5\% } & 17,684
\end{tabular}

Keterangan: Dua nilai tengah yang diikuti dengan huruf yang sama tidak berbeda menurut uji BNT pada selang kepercayaan $\alpha 5 \%$. 
persen infeksi akar pada perlakuan FMA jenis Glomus sp. isolat MV 10, Gigaspora sp. isolat MV 17, dan Entrophospora sp. isolat MV 2 tidak diikuti dengan meningkatnya pertumbuhan tanaman. Diperkirakan bahwa hifa eksternal yang terbentuk pada perlakuan Glomus sp. isolat MV 10, Gigaspora sp. isolat MV 17 dan Entrophospora sp. isolat MV 2 rendah, sehingga kemampuan FMA dalam menyerap unsur hara dan air rendah dan belum dapat meningkatkan pertumbuhan tanaman. Hifa eksternal FMA pada akar tanaman dapat memperluas bidang serapan akar yang tumbuh dan berkembang melalui bulu akar (Talanca, 2010). Berbeda dengan perlakuan FMA jenis Glomus sp. isolat MV 27 dan Entrophospora sp. isolat MV 29 yang memiliki persen infeksi akar yang tinggi dan pertumbuhan tanamannya juga meningkat. Diperkirakan bahwa hifa eksternal yang terbentuk pada perlakuan Glomus sp. isolat MV 27 dan Entrophospora sp. isolat MV 29 juga tinggi, sehingga unsur hara yang diserap juga tinggi. Hal ini dapat dilihat berdasarkan jumlah daun, diameter batang, bobot kering akar dan bobot kering tajuk yang meningkat. Jumlah daun dan diameter batang tertinggi diperoleh pada bibit kelapa sawit yang diinokulasikan FMA jenis Glomus sp. isolat MV 27 tidak berbeda nyata dengan Entrophospora sp. isolat MV 29 (Tabel 3). Hal ini dapat terjadi karena unsur hara yang diserap oleh FMA akan digunakan oleh tanaman dalam proses pembelahan sel. Pembelahan sel pada area pucuk akan membentuk daun baru, sehingga akan meningkatkan jumlah daun (Sari et al., 2016).

Dengan meningkatnya jumlah daun maka proses fotosintesis semakin meningkat sehingga lebih banyak fotosintat yang dihasilkan dari proses fotosintesis tanaman. Fotosintat tersebut diedarkan ke seluruh bagian tanaman termasuk batang. Menurut Cavagnaro et al. (2003), efektivitas simbiosis FMA dapat dilihat berdasarkan kemampuan FMA dalam meningkatkan bobot kering tanaman. Bobot kering tajuk tanaman tertinggi diperoleh pada bibit kelapa sawit yang diinokulasikan FMA jenis Entrophospora sp. isolat MV 29 yang tidak berbeda nyata dengan Glomus sp. isolat MV 27 (Tabel 4). Unsur hara dan air yang diserap oleh FMA digunakan tanaman dalam membantu proses metabolisme tanaman. Produk dari seluruh metabolisme tanaman adalah bobot kering tanaman. Menurut Musfal (2010), bobot kering tanaman mencerminkan

Tabel 3. Data jumlah daun dan diameter batang bibit kelapa sawit umur 28 MST yang telah diinokulasi 5 jenis FMA

\begin{tabular}{|c|c|c|}
\hline Perlakuan & Nilai tengah jumlah daun & Nilai tengah diameter batang \\
\hline & -------------helai------------ & -----------------cm---------------- \\
\hline Tanpa Mikoriza & $9,3 \mathrm{~b}$ & $3,32 \quad b$ \\
\hline Glomus sp. Isolat MV 10 & $8,8 \mathrm{~b}$ & $3,16 \quad b$ \\
\hline Glomus sp. Isolat MV 27 & $10,5 \quad \mathrm{a}$ & 4,02 a \\
\hline Gigaspora sp. Isolat MV 17 & $8,8 \quad \mathrm{~b}$ & $3,29 \quad b$ \\
\hline Entrophospora sp. Isolat MV 2 & $9,3 \mathrm{~b}$ & $3,39 \mathrm{~b}$ \\
\hline Entrophospora sp. Isolat MV 29 & $10,5 \quad \mathrm{a}$ & $3,98 \quad \mathrm{a}$ \\
\hline BNT 5\% & 1,1 & 0,59 \\
\hline
\end{tabular}

Tabel 4. Data bobot kering tajuk dan bobot kering akar bibit kelapa sawit umur 28 MST yang telah diinokulasi 5 jenis FMA

\begin{tabular}{lrlll}
\hline \multicolumn{1}{c}{ Perlakuan } & Nilai tengah bobot kering tajuk & Nilai tengah bobot kering akar \\
\hline & & & \\
Tanpa Mikoriza & 20,3 & $\mathrm{bc}$ & $6,5 \mathrm{ab}$ \\
Glomus sp. Isolat MV 10 & $19,2 \mathrm{c}$ & $5,2 \mathrm{~b}$ \\
Glomus sp. Isolat MV 27 & $29,2 \mathrm{ab}$ & $7,4 \mathrm{ab}$ \\
Gigaspora sp. Isolat MV 17 & $20,0 \mathrm{bc}$ & $5,9 \mathrm{ab}$ \\
Entrophospora sp. Isolat MV 2 & $20,3 \mathrm{bc}$ & $5,8 \mathrm{ab}$ \\
Entrophospora sp. Isolat MV 29 & $30,7 \quad \mathrm{a}$ & $8,3 \mathrm{a}$ \\
\hline \multicolumn{1}{c}{ BNT 5\% } & 9,9 & 2,9 \\
\hline
\end{tabular}

Keterangan: Dua nilai tengah yang diikuti dengan huruf yang sama tidak berbeda menurut uji BNT pada selang kepercayaan $\alpha 5 \%$. 
banyaknya unsur hara yang diserap oleh tanaman. Semakin berat bobot kering tanaman, pertumbuhan tanaman akan semakin baik dan unsur hara yang diserap tanaman juga semakin banyak.

Pertumbuhan tanaman kontrol lebih baik dibandingkan dengan tanaman yang diberi FMA jenis Glomus sp. isolat MV 10, Gigaspora sp. isolat MV 17, dan Entrophospora sp. isolat MV 2 pada beberapa variabel (Gambar 1, Tabel 3, dan Tabel 4). Hal ini diduga karena spora indigenous yang menginfeksi tanaman kontrol lebih efektif dalam meningkatkan pertumbuhan bibit kelapa sawit, sehingga bibit kelapa sawit tanpa FMA pertumbuhannya lebih baik dibandingkan dengan FMA jenis Glomus sp. isolat MV 10, Gigaspora sp. isolat MV 17, dan Entrophospora sp. isolat MV 2. Menurut Suhardi (1988), FMA indigenous lebih efesien dalam meningkatkan pertumbuhan tanaman karena sudah beradaptasi dengan lingkungan sekitar dibandingkan dengan FMA yang baru diinokulasikan. Susila et al. (2016) menyatakan bahwa penggunaan mikoriza indigenous pada tanaman padi lebih adaptif dan efektif dalam perkembangannya, sehingga kemampuan dalam menyerap unsur hara dan air semakin tinggi dan dapat meningkatkan kecepatan pertumbuhan tanaman.
Pada penelitian ini diduga seluruh perlakuan selain terinfeksi FMA yang diinokulasikan juga terinfeksi oleh spora indigenous. Hal ini dibuktikan dengan ditemukannya vesikel pada akar bibit kelapa sawit yang diinokulasi FMA jenis Gigaspora sp. Isolat MV 17 (Gambar 2). FMA jenis Gigaspora seharusnya tidak membentuk vesikel. Menurut Brundrett (2008), genus Gigaspora dan Scutellospora tidak membentuk vesikel. Genus ini menghasilkan organ yang membengkak dan berkerumun dengan duri-duri pada hifa eksternal yang disebut dengan auxilary cell. Vesikel yang terdapat pada akar tersebut diduga berasal dari spora indigenous yang menginfeksi akar bibit kelapa sawit.

Dengan adanya FMA indigenous yang menginfeksi akar bibit kelapa sawit, maka terjadi persaingan antara FMA indigenous dan FMA eksogenus (FMA yang diaplikasikan). FMA jenis Gigaspora sp. isolat MV 17, Glomus sp. isolat MV 10, dan Entrophospora sp. isolat MV 2 diduga tidak mampu bersaing dengan FMA indigenous yang ada. Hal ini terlihat dari pertumbuhan tanaman yang kurang optimal. Namun berbeda dengan yang terjadi pada FMA jenis Glomus sp. isolat MV 27 dan Entrophospora sp. isolat MV 29 yang tetap meningkat

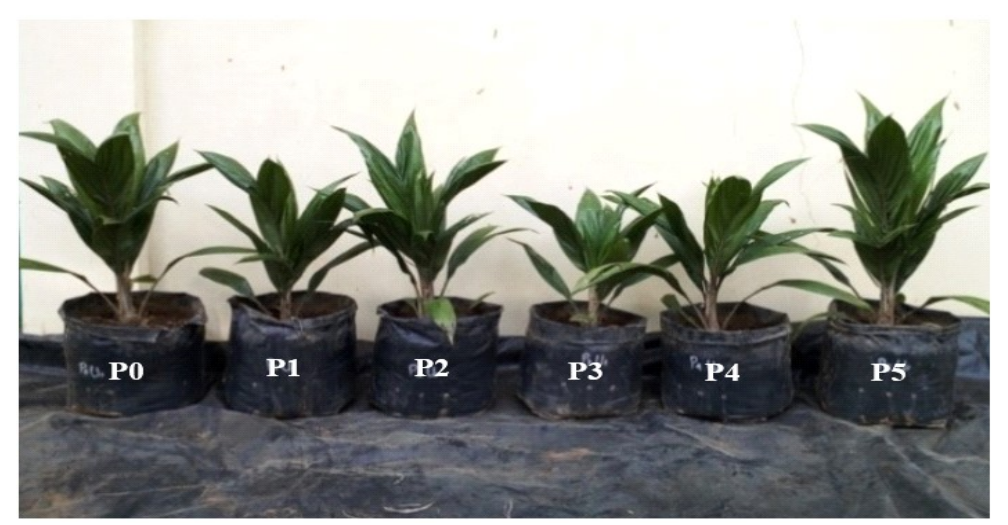

Gambar 1. Bibit kelapa sawit yang diberi perlakuan P0 (kontrol), P1 (Glomus sp. Isolat MV 10), P2 (Glomus sp. isolat MV 27), P3 (Gigaspora sp. isolat MV 17), P4 (Entrophospora sp. isolat MV 2), P5 (Entrophospora sp. isolat MV 29).

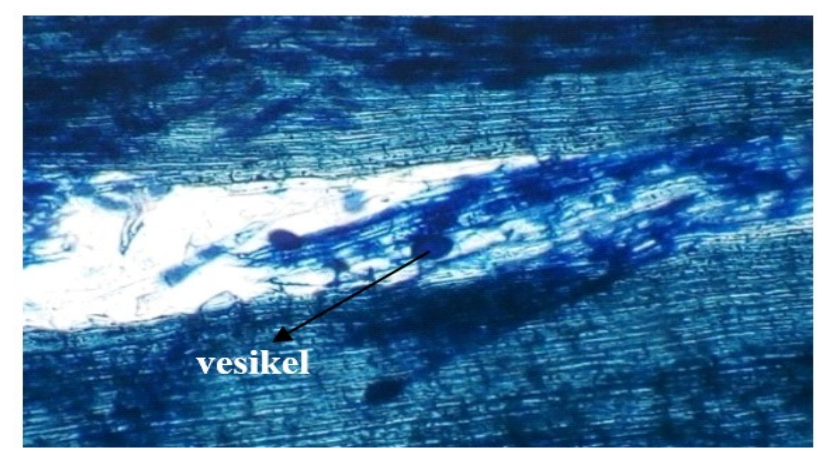

Gambar 2. Vesikel yang terdapat pada akar bibit kelapa sawit yang diinokulasi FMA jenis Gigaspora sp. isolat MV 17. 
pertumbuhannya, hal ini diduga karena FMA jenis Glomus sp. isolat MV 27 dan Entrophospora sp. isolat MV 29 mampu bersaing dengan FMA indigenous yang ada sehingga dapat meningkatkan pertumbuhan tanaman. Menurut Novriani dan Madjid (2009), salah satu indikator FMA dapat dikatakan efisien penggunaanya apabila mampu bersaing dengan mikroorganisme lain untuk menginfeksi dan mengabsorbsi nutrisi ke akar tanaman dan mampu mentransfer nutrisi tersebut ke tanaman.

\section{KESIMPULAN}

FMA jenis Entrophospora sp. isolat MV 29 dan Glomus sp. isolat MV 27 merupakan FMA yang terbaik untuk pertumbuhan bibit kelapa sawit dibandingkan dengan FMA lainnya dan tanpa FMA yang dilihat melalui nilai tengah jumlah daun sebesar 10,5 helai, nilai tengah bobot kering tajuk sebesar $30,7 \mathrm{~g}$ dan 29,2 g, nilai tengah diameter batang sebesar 3,98 cm dan 4,02 cm dan nilai tengah persen infeksi akar sebesar 82,9\% dan 75,8\%.

\section{DAFTAR PUSTAKA}

Allen, M. F. 2001. Modeling Arbuscular Mycorrhizal Infection: is \% Infection an Appropriate Variable. Mycorrhiza J. $10: 255-258$.

Atkinson, D. 2000. Root characteristics: Why and What to measure. In A. L. Smit etal (eds) Root methonds A Handbook. Heidelberg, Springer, Verlag. $32 \mathrm{hlm}$.

Brundrett, M. N. Bougher, B. Dell. Gove dan Malajczuk, N. 1996. Working with Mycorhizas in Forestry and Agriculture. Australia Center for International Agricultural Research (ACIAR). Camberra. 374 hlm.

Brundrett, M. C. 2008. Mycorrhizal Association: The Web Resource. https://mycorrhizas. info/ vam.html. Diakses pada 3 April 2017.

Cavagnaro, T. R., Smith, F. A., Ayling, S. M., Smith, S. E. 2003. Growth and Phosphorus Nutrition of A Paris-type Arbuscular Mycorrhizal Symbiosis. New Phytol. 157:85-89.

Hadi, A. M. 2011. Pengaruh Pemberian Glomus sp., Gigaspora sp., Entrophospora sp., dan Dua Dosis NPK pada Pertumbuhan Bibit Kelapa Sawit (Elaeis guineensis Jacq.) di Pembibitan. Skripsi Fakultas Pertanian Universitas Lampung. Bandar Lampung. $65 \mathrm{hlm}$.
Iskandar, D. 2002. Pupuk Hayati Mikoriza untuk Pertumbuhan dan Adapsi Tanaman di Lahan Marginal. PPKS RISPA. Medan. 58hlm.

Lakitan, B. 2012. Dasar-dasar Fisiologi Tumbuhan. Rajawali Pers. Jakarta. 206 hlm

Musfal. 2010. Potensi Cendawan Mikoriza Arbuskula untuk Meningkatkan Hasil Tanaman Jagung. Jurnal Litbang Pertanian. 29 (4): 154-158.

Novriani dan Majid. 2009. Peran dan Prospek Mikoriza. Universitas Sriwijaya: Palembang. http://www.scribd.com/doc/22391846/PeranDan-Prospek-Mikoriza. Diakses pada 12 Maret 2016.

Prayudianingsih, R. dan Sari, R. 2016. Aplikasi Fungi Mikoriza Arbuskula (FMA) dan Kompos untuk Meningkatkan Pertumbuhan Semai Jati (Tectona grandis Linn.f.) pada Media Tanah Bekas Tambang Kapur. Jurnal Penelitian Kehutanan Wallacea. 5(1): 37-46.

Rini, M. V. Utoyo, B., dan Timotiwu, P. B. 2010. Populasi Keragaman Fungi Mikoriza Arbuskular pada Perkebunan Kelapa Sawit di Tanah Mineral dan Gambut. Prosiding Seminar Nasional Keragaman Hayati Tanah H-1. Bandar Lampung. 29-30 Juni 2010. 208-218.

Sari, A., Noli, Z. A., dan Suwirmen. 2016. Pertumbuhan Bibit Surian (Toona sinensis (Juss,) M. Roem) yang Diinokulasi Mikoriza pada Media Tanam Tanah Ultisol. AlKauniyah Jurnal Biologi. 9 (1):1-9.

Smith, S. E., dan Read, D. J. 2008. Mycorrhizal Symbiosis. Academic Press. London. $800 \mathrm{hlm}$.

Suhardi. 1988. Cendawan Mikoriza Vesikular Arbuskular. Pedoman Kuliah. PAUBioteknologi Universitas Gadjah Mada. Yogyakarta. $178 \mathrm{hlm}$.

Susila, E., Elita, N., dan Yefriati. 2016. Uji Isolat FMA Indigenous terhadap Pertumbuhan dan Infeksi Akar Tanaman Padi Metode SRI. Jurnal Pros Sem Nas Masy Biodiv Indon. 2 (1): 71-75.

Talanca, H. 2010. Status Cendawan Mikoriza Vesikular-Arbuskular (MVA) pada Tanaman. Prosiding Pekan Serealia Naional. Sulawesi Selatan. 353-357. 